\title{
DOS “ERROS” \\ E EM ESPECIAL DAQUELE DE RENUNCIAR À EDUCAÇÃO \\ NOTAS SOBRE PSICANÁLISE E EDUCAÇÃO
}

\author{
Leandro de Lajonquière \\ A Cecilia e Luci, pelas conversas sobre a escola perdida. \\ "...é a psicanálise que está fadada a estabelecer, no \\ momento oportuno, um problema político". \\ Educação Impossivel. \\ Maud Mannoni
}

$s$ termos problemas, dificuldades ou distúrbios de aprendizagem, bem como erro e fracasso escolar equivalem-se simbolicamente no atual espírito (psico) pedagógico hegemônico. Por outro lado, tem se tornado hábito esgrimir, alternativa ou conjuntamente, como causas dos mesmos a falta de maturação das capacidades cognitivo-afetivas da clientela escolar e a ineficácia dos métodos de ensino utilizados circunstancialmente.

Assim, um punhado de capacidades, como também um catatau de métodos mais ou menos adequados, um sem-número de erros, dificuldades, problemas e distúrbios de aprendizagem fazem as vezes de uma ontologia educativa mínima. Trata-se de verdadeiras criaturas cujo pavonear ofusca os espíri-

Psicanalista, Doutor em Educação pela UNICAMP. Atualmente é professor-doutor do Depto. de Filosofia e Ciências da Educação da Universidade de São Paulo e pesquisador do CNPq 
tos, ao ponto tal que não poucos já não podem pensar em outra coisa. Em nosso país, são numerosos os esforços governamentais bem como as pesquisas acadêmicas que visam insistentemente domesticá-las, prevenir sua reprodução, descobrir o segredo de seu regime alimentar ou simplesmente torná-las criaturas em extinção, graças à administração de métodos naturalmente adequados aos estados singulares, devidamente conhecidos, das capacidades maturacionais de plantão.

Dessa forma, o cotidiano escolar acabou sendo, de direito e de fato, psicologizado. Por um lado, a cena educativa foi sendo ocupada, cada vez mais, por aqueles que a principio foram cogitados apenas como extras ou para-educativos. Como sabemos, esses especialistas, detentores de uma certa cultura $p s i$, são, hoje, os que, avaliando, prognosticando, justificando os insucessos educativos, roubam o papel do educador de outrora. Por outro lado, virou hábito acreditar que a potestade educativa de toda empresa é função da adequação natural entre capacidades e estratégias de administração de estímulos pedagógicos. Isto é, pensa-se que a educação só é possível na proporção dessa conjunção e, portanto, que qualquer tentativa não dedutível do prospectivo cálculo desenvolvimentista carece a priori de toda pertinência.

Em suma, o campo educativo passou a se articular a partir de um ponto de fuga sui generis -aquele recortado no horizonte pela junção assintótica de semelhante função ilusória. O que, em bom português, significa que o axioma "educar é desenvolver capacidades" está sempre, em maior ou menor medida, bem como explícita ou implicitamente, embutido tanto nas grandes quanto nas pequenas decisões pedagógicas. Obviamente, colocada a problemática nesses termos, a chave da mesma sempre estará nas mãos daqueles que possuem um conhecimento a mais sobre o dito desenvolvimento.

O processo de psicologização da educação e em especial da escolar, originado, embora com intensidades e características singulares, nas primeiras décadas deste século na maioria dos países sedentos de ordem e progresso, acabou adquirindo, sem dúvida nenhuma, no nosso país dimensões inusitadas. Assim, não é por acaso que, hoje em dia, constatemos com certa facilidade o seguinte:

- Não poucas escolas propalam, insistentemente, o fato de possuir todo tipo de especialistas na prevenção e cura dos ditos problemas de aprendizagem. Esse recurso revela-se um bom chamariz, bem como parece ser uma espécie de garantia espiritual para boa parte dos próprios educadores;

- Uma certa religiosidade metodológica toma conta, cada vez mais, dos espíritos pedagógicos até o extremo de, por um lado, a maioria colocar o destino da empresa educativa nas mãos de deuses, cujas idades não ultrapassam o tempo da última troca de pedo-burocratas e, por outro, as escolas passam a se identificar 
entre si conforme a cartilha que rezam;

- A psicologia da educação acabou virando "a bendita" dentre todas as assim chamadas, e outrora respeitadas por igual, ciências da educação;

- A própria psicologia da educação é, não poucas vezes, considerada uma psicologia menor "para os educadores virem a conhecer mais sobre o desenvolvimento". Ignorando-se, assim, o espírito disciplinar originário no sentido da compreensão psicológica da dinâmica própria do processo educativo;

- Os campos clínicos e educativos acabaram superpostos a tal ponto que, por um lado, considera-se pertinente fundar uma educação escolar nos moldes de diferentes intervenções psicológicas e, por outro, pensa-se que a intervenção clínica (em especial, a psicopedagógica) é isomórfica à prática escolar, porém, "um pouco mais devagar e personalizada".

- Pensa-se que o fracasso escolar é o produto do somatório dos ditos erros ou problemas de aprendizagens, bem como, que esses resultam da nãoadequação dos métodos aos estados singulares das capacidades da clientela.

Ao nosso ver, o inflacionamento psicológico está, precisamente, em causa, na inversão dos diversos efeitos perseguidos. Num texto recente ${ }^{1}$ tentamos mostrar, por exemplo, até que ponto a dita indisciplina escolar - objeto mutante de prevenção e controle - é um efeito paradoxal da própria forma de se colocar a problemática ensinoaprendizagem no seio do espírito (psico)pedagógico hegemônico. Mais ainda: hoje, declaramos estar persuadidos que ela acabou transformando a educação numa empresa, em princípio, impossível de vir a acontecer de fato ou, então, de difícil acontecimento. Por sinal, não era essa impossibilidade fatual à qual Freud fez referência, quando colocou na mesma encruzilhada a arte do governo, da psicanálise e da educação, e que hoje tanto se propala. Com efeito, o pai da psicanálise se referia a uma certa impossibilidade estrutural ou de direito, que se aninha em todo ato educativo.

Nesse sentido, cabe afirmar que o consabido fracasso escolar não é o efeito inevitável da impossibilidade educativa da qual fala a psicanálise, mas da tentativa sintomática que o discurso (psico)pedagógico hegemônico propõe, precisamente, para equacioná-la.

\section{A EDUCAÇÃO ENTRE O CONHECIMENTO E O SABER}

Educar vem do latim educare que significa criar, alimentar, ter cuidados com, adestrar animais, formar e instruir. Por outro lado, parece ser que adquire só a partir do século XVII, ao menos na língua castelhana, um caráter menos material e limitado que seu sinônimo originário criar. Por sinal, talvez seja por isso que em francês os alunos são chamados "élèves", termo que deriva da expressão "élever des animaux". Em sua acepção poética, educar significa moldar, esculpir, escrever. É nesse sentido que aparece, por exemplo, na frase "teneros mores seu pollice ducere", isto é, "moldar os caráteres tenros como com o polegar". Assim sendo, na educação atualiza-se algo da ordem de uma marca que molda, possibilita certa condição existencial, bem como burila o ímpeto próprio da "animalidade".

Em suma, perece ser pertinente afirmar que educar significa, simplesmente: endireitar. Quiçá essa palavra desagrade os espíritos politicamente corretos ou reavive pesadelos em alguns dos mais velhos. Entretanto, reafirmamos que é disso que se trata na educação, tanto escolar quanto familiar, 
embora seja num outro sentido - o metafórico.

Em toda educação está em questào a transmissão de um conjunto parcial de conhecimentos ou uma amostra daquilo que os outros souberam acumular com antecedência. Porém, aquele que aprende algo não só adquire um certo domínio sobre algum dos mundos possíveis -aqueles das letras, da natureza, ou das virtudes humanas, dentre outros - mas também, é marcado pelo apre(e)ndido no próprio coração da vida.

Quando o aprendiz adquire o domínio de uma série de conhecimentos, acaba se parecendo um pouco com seu mestre. Mais ainda, quando apr(e)ende o que antes era apenas detentado por delegação pelo mestre -um algoritmo histórico-mundano de interação com o real ${ }^{2}$ - acaba assujeitado, mesmo que seja por um fio, a toda uma tradição. Por exemplo, Pedrinho apre(e)ende os números, porque alguém the ensinou, mesmo que não tenha sido escolarmente. Então, de agora em diante, por um lado, o mundo sempre lhe aparecerá como numerável de forma tal que não poderá deixar de lutar epistemicamente com ele numa outra forma que não seja sob a legalidade $n+1$; e, por outro, Pedrinho, seu mestre e o mestre do mestre passam a ter alguma coisa em comum. Assim sendo, o conhecimento trasmitido não deixa de ser o embrulho de uma marca de pertinência ou um traço identificatório. Em outras palavras, trata-se de uma marca que em si mesma carrega uma dose de existência, ou seja, uma cota de saber fazer com a vida.

Toda educação pressupõe, também, a transmissão de um certo saber existencial que não se reduz ao conbecimento sobre nenhum mundo possível. $O$ fato de aprender os números possibilita a um sujeito, por exemplo, contar ovelhas numa noite de insônia, bem como calcular o intervalo de tempo existente entre os transbordamentos de um rio. Entretanto, a reconstrução em-si e para-si de um conhecimento qualquer, além de ter efeitos mais ou menos utilitários em diferentes registros da sobrevivência de alguém, extende as fronteiras da vida. Com efeito, agora, o sujeito tanto passa a noite acompanhado por outros insones contadores de ovelhas, quanto percebe que seus vizinhos estão tomando providências e não fazendo excentricidades próprias dos extraterrestres. Isto é, o sujeito passa a fazer como os outros já vinham fazendo há algum tempo e, portanto, sua parca vida se existencializa. O sujeito além de ganhar um certo passatempo ou melhores condições para se proteger da traiçoeira natureza, deixa de estar a sós. Isso, como sabemos, coloca uma série de problemas dependendo da companhia. Porém, aquilo que nem a melhor das companhias consegue impedir que acabe se colocando em questão é o preço da mesma, que não é outro que o tamanho da dívida pela própria existência.

Assim, quando os pais "ensinam" seu filho quem, em parte, ele é para os outros (a começar por eles mesmos), colocando-lhe um nome que vectoriza certos ideais, como também quando uma professora ensina a Pedrinho os números, instala-se uma divida. O filho em questão e o Pedrinho de plantão passam a dever algo pela sua existência, enquanto filho de alguém ou, simplesmente, enquanto humano, pois, por exemplo, os animais são seres que, além de não possuirem amor filial, não acreditam em números.

Como sabemos, uma coisa é dever uma quantia xis de dinheiro para um amigo e outra, muito diferente, é o preço da amizade. Com os nomes e os números ocorre algo parecido: todo res- 
peito será pouco para saldar a divida pela existência ou, em outras palavras, o pouco sentido que a vida pode ter acabado de ganhar. No valor incalculável da mesma está embutida uma infindável pergunta: o outro, o que quer de mim?

Dessa forma, embora o nome e os números aprendidos tirem um bocado da estupidez da vida empírica, o ato de ensinar (re)instala ou marca a fogo aquela mesma pergunta. Se o leitor se detém um pouco sobre o assunto, logo verá que se trata de um paradoxo necessário. Com efeito, ter certeza sobre o que o outro quer de mim obrigame a pagar a dívida com a própria existência; entretanto, se o outro nada quer de mim, então, não há existência alguma a ser devida senão, apenas, vida a ser vivida ou gozada na sua solidão. O chamado desejo é precisamente o eco da natureza não-conclusiva dessa pergunta.

Sobre o desejo não há conbecimento algum, mas, saber 3 . O saber sobre o desejo é um certo savoir faire cujo grande valor reside na sua fútil inutilidade, uma vez que o mundo sobre o qual versa é aquele do impossível. Esse saber, ao contrário dos conhecimentos, não se estrutura em sistemas cada vez mais equilibrados conforme algum ponto virtual de referência histórico-mundana. O saber sobre o desejo apenas se articula nas vicissitudes da existência, pois sua natureza é da ordem de um paradoxo, qual seja: querer saber sobre o desejo e não querer saber que é impossivel saber que não há saber sobre o desejo. Assim, cabe frisar que o saber sobre o desejo -sobre o não-possível- é, em última instância, o saber da mesmíssima impossibilidade. Nesse sentido, o saber sobre o desejo não deixa de ser o saber não-sabido recalcado- do desejo ${ }^{4}$.

A divida de todo aprendiz para com seu mestre ocasional é de natureza estritamente simbólica. Por um lado, o trasmitido -uma série de conhecimentos sobre mundos possíveis, bem como um fragmento não-sabido do saber- é da ordem do símbolo (da representação, da metáfora) e não das coisas. Por outro, é também simbólica no sentido em que o aprendiz nada deve no real, pois o transmitido não era, em última instância, do mestre. Ele doa, de fato, por delegação ou direito, aquilo que não deixa de ser sempre propiedade de uma tradição guardiã de sistemas epistêmicos. No entanto, isso não significa que o mestre seja um vigarista que empresta como se fosse dele objetos que pertencem a outros. Ele se autoriza, devidamente, invocando a potestade graciosa própria da tradição dos mestres honrados. Mais ainda, é essa invocação - e o reconhecimento da dívida nela embutida - que outorga caráter verdadeiramente simbólico ao transmitido. $O$ transmitido, em lugar de ser um simples indice do amor magistral, é um signo sui generis -um significante- tanto da dívida do mestre pelo empréstimo parcial do qual goza, quanto do desejo em causa no ato educativo.

Por outra parte, quando alguém ensina está colocando alguma coisa em signos, ou seja, está ensi(g)nando ou fazendo alusão. O transmitido é uma in/sígnia ou fragmento mais ou menos tradicional de uma totalidade epistêmica e não todo o conhecimento que qualquer aprendiz, alguma vez, supôs a um mestre circunstancial. Assim, uma parte se transmite; mas ela não é toda a episteme.

No entanto, na educação está também em questão a transmissão de um certo saber, não redutível à ordem dos conhecimentos, sob a forma do (que é) ideal. Precisamente, em todo ato educativo há embutido uma cota de dever ser. Assim, quando alguém ensina os núme- 
ros está dizendo ao aprendiz que chegar a conhecer o resultado de $2+2$ é tanto uma forma de vir a ser um pouco matemático quanto o dever de qualquer um que se preze um crente em números. Mais ainda, o nome que os pais colocam no filho faz também alusão a uma série de ideais ou conjunto quase sempre heteróclito de mandatos existenciais. De fato, todo nome costuma encerrar deveres do tipo: vir a ser um a mais como o avô na série dos seres honrados ou vir a ser um homem que como o pai renunciou à sua própria mãe. Porém, na educação, não só se trata da veiculação de ideais de ordem simbólica senão também de ideais imaginários. $\mathrm{O}$ ideal é imaginário quando não assume a forma de um dever ser, paradoxalmente, sempre retrospectivo, mas aquela de um mandato que se auto-esvazia de futuro no presente mesmo de sua formulação. É verdade que a injunção de vir a ser, por exemplo, um pouco matemático, honrado ou homem, sempre arrasta consigo uma fatia de folclore imaginário. No entanto, o ideal imaginário é simplesmente um mandato feito de puro estofo especular; isto é, trata-se do pedido de complementação narcísica daquele mesmo que o enuncia. Assim, o ideal, em vez de levar embutido $u m$ dever ser-uma dívida para com o passado dos homens ou das matemáticas-, encerra em si mesmo o dever de ser a metade que ao mandante lhe falta para ser de fato, lembrando Freud, o Ego-Ideal. Os Ideais do Ego, enquanto simbólicos, não têm por missão formatar a falta do/no sujeito, visto que precisamente assinalam, por exemplo, que a vida honrada do avô não se confunde com a honra, bem como o fato de renunciar à mãe não é ponto de chegada, mas de partida, para ser um homem. Como vemos, quando o ideal é simbólico, o saber veiculado é um saber-não sabido, pois, embora no horizonte se recorte uma razão de ser, o sujeito nunca virá a saber certamente sobre a diferença entre ser e dever ser o ideal, no seio da qual aninha-se o desejo. Ao contrário, o ideal imaginário veicula um saber mais parecido com a certeza; então, aquele que recebe a injunção de ser, agora, não só sabe o que lhe estão pedindo senão também como é que se faz para ser. À vista disso, esse saber sobre o desejo passa a ser um saber de fato sabido e, portanto, o veiculado acaba se revelando não um desejo mas um voto de gozo.

Dessa forma, em toda empresa educativa, além dos conbecimentos transmitidos efetivamente, há algumas quantas coisas que, pelo contrário, perpassam em negativo no seio do ato. É o caso, precisamente, da própria alusão ao todo epistêmico impossível de ser veiculado na sua totalidade, da doação dos ideais que toma a forma de um dever-ser endividado, do saber sobre o desejo que revela ser ou um saber-não sabido ou uma certeza (isto é, um nãosaber), bem como o desejo que, embora transmitido, sempre é do Outro.

Neste contexto, cabe afirmar que conhecimento, saber, desejo e dívida simbólica se pressupõem e se articulam em toda educação. Mais ainda, cabe concluir que educar nåo é nada mais que 
o corriqueiro pôr em ato de um processo de filiação ou assujeitamento a ideais, desejos, sistemas epistêmicos e dívidas.

Justamente, a educação, na medida em que filia, entre (os) outros, o mestre de plantão e o aprendiz circunstancial a uma tradição existencial, possibilita que cada um se reconheça no outro; isto é, que cada um reconheça que o outro porta uma marca semelhante à sua. Essa marca, enquanto traço do mesmo ato, faz do outro um espelho onde é possível ver-se ou reconhecer-se direito. Ora pois, não devemos nos surpreender que a educação nos endireite na vida ou que seja graças a ela que venhamos a ter uma existência mais ou menos reta.

\section{ENSINA-SE POR DEVER, APRENDE-SE POR AMOR}

Todo ato educativo que se preze veicula sempre algo da ordem dos conhecimentos mais ou menos utilitários, bem como um punhado de saberes existenciais.

Por outra parte, todo aquele que ensina o faz, obviamente, porque, alguma vez, deve ter aprendido, ao menos, aquilo que tenta transmitir. Aquilo que o mestre ensina, embora seja dele pois $\mathrm{o}$ apr(e)endeu, não lhe pertence. $\mathrm{O}$ aprendido é sempre emprestado de alguma tradição que já sabia o que fazer com a vida. Assim, aquele que aprende de fato contrai automaticamente uma dívida que, embora acredite às vezes têla com seu mestre ocasional, está em última instância assentada no registro dos ideais ou do simbólico.

Dessa forma, como todo mestre foi alguma vez aprendiz, ele não passa de um devedor. Pois bem, por que o mestre ensina? Aquilo que ensina é uma amostra "de que" e "do que" deve. Em 
outras palavras, aquilo que o mestre mostra, para assim educar o aprendiz de plantão, é a prova de seu dever. Em suma, o mestre ensina porque afinal de contas esse é seu dever. Mais ainda, ensinar é de fato sua própria e justa sina.

O mestre não pode não ensinar o que aprendeu uma vez que o apre(e)ndido leva consigo um pecado de origem, qual seja, o de uma dívida que, embora reconhecida, não pode de fato ser saldada. Essa dívida é simbólica, pois aquele que ensina não faz mais que emprestar da tradição. Ao contrário, qualquer dívida nossa da vida cotidiana pode ser cancelada sem muita cerimônia -claro está, na medida em que o tomador não se pareça com o freudiano Homem dos Ratos. No entanto, quando ela é simbólica pode ser apenas equacionada. Nesse caso, tentar devolver para o mestre, por um lado, não tem cabimento, pois, o emprestado não era dele e, por outro, é impossível já que sendo o apre(e)ndido da ordem do símbolo, seu valor sofre alterações quando da sua transmissão. Assim, quando a dívida é simbólica pouco adianta querer voltar atrás e dizer para o mestre "não está aqui quem aprendeu". Insistir por essa via apenas adianta na exata proporçåo da culpa provisoriamente abatida daquele que tomou, como sendo dele, o que era de um outro (isto configura um roubo, pois outra coisa é tomar do Outro). Ao contrário, uma dívida simbólica pode ser só amortizada na exata medida em que seja reconhecida como tal.

Reconhecer uma dívida simbólica pode parecer à primeira vista um ato menor, do tipo "sair brincando quando o lobo não está", visto que o credor parece estar mais para um espectro que para o lobo da historieta dos três porquinhos ou para um agente do FMI. Porém, cabe afirmar que não se trata de nada simples de driblar, pois reconhecer a natureza simbólica da dívida em questão é aceitar (inconscientemente) a castração. Reconhecer a dívida significa que o aprendiz, por um lado, declara ter tomado emprestado e, por outro, aceita que o emprestado acarreta uma eleição. Por exemplo, aprender os números me obriga a fazer contas conforme uma legalidade e não outra como, aliás, fazem-no todos os sujeitos que são um pouco matemáticos. Mais também, tê-los aprendido me obriga a fazer uma escolha a respeito dos saberes ou ideais veiculados pelo mestre do tipo "para ser matemático tem que se dedicar o tempo todo aos números". Entretanto, uma coisa são as obrigações contidas nos ideais e outra diferente é a obrigação de reconhecer o fato de que o mesmíssimo ideal está em causa. Todo ideal manda escolher entre ele e um outro. Logo, a escolha embutida nele se revela, em última instância, isomórfica àquela de ter que optar entre "a bolsa ou a vida" (cf.Lacan,1985,p.193-204). Como sabemos, semelhante escolha não é sem consequências. Assim sendo, reconhecer a dívida não é nem mais nem menos que aceitar a vida que só o símbolo pode dar: uma vida à qual falta sempre um outro tanto para ser o ideal.

Poder-se-ia pensar que reconhecer a imperfeiçåo da vida e o 
caráter ideal do símbolo autoriza o sujeito a ser um cínico, escravo do "tanto faz" - como se apre(e)nde sempre menos que o ideal, então posso fazer vista grossa ao fato de que o por mim conhecido e ensinado não seja o ideal. Entretanto, o reconhecimento da irredutibilidade daquela diferença obriga paradoxalmente o sujeito a sempre tentar mais uma vez um ato que honre o ideal. Em outras palavras, a lembrança dessa diferença condena o sujeito a não renunciar a um ato, cujo único fundamento não é outro que a dívida simbólica para com o injustificável dever de arriscar.

O sujeito lembrando-se e lembrando outros do dever-ser, na imperfeição de cada ato, mantém viva a natureza ideal do simbólico. Se porventura ele não lembrar o/do dever, o ideal deixaria, simplesmente, de ser tal, bem como o próprio sujeito perderia seu rumo existencial.

Assim, o mestre, que alguma vez aprendeu, ensina para lembrar que, embora o mostrado não seja nem toda a episteme nem todo o saber, aprender é condição sine qua non para ter acesso simbólico a eles. Porém, se o mestre, por exemplo, aquele um pouco matemático, renunciar a manter viva a lembrança da sua dívida existencial para com as matemáticas e decide abrir mão da dignidade de seu ensino, o mundo dos números vira letra morta, bem como o mestre perde um pouco de seu ser. Em suma, o mestre não pode recusar-se a ensinar, pois o aprendido por ele morreria, da mesma forma que uma língua, quando deixa de ser falada, acaba virando mais uma língua morta.

O aprendiz, ao contrário do mestre, que atua por dever, é movido na sua tarefa por amor. Quando o mestre oferta seu ensino, instala no seu interlocutor o desejo de saber mais sobre aquilo que cai no ato da transmissão, bem como alimenta o amor do aprendiz por aquele que the aparece como sabendo disso que faz falta nele. A princípio pode parecer paradoxal, mas, comme d' babitude, a oferta está na origem da demanda 5 .

Por que razão alguém iria tanto desejar saber quanto amar ao outro antes mesmo que lhe tenha sido feita alguma oferta magistral? Com efeito, antes da oferta não há razão alguma, à exceção, claro está, para quem professa o típico naturalismo que pressupõe um saber existencial à matéria, ainda, de fato, virgem.

$O$ ato de ensinar instaura, retrospetivamente, um tempo no qual o sujeito estava desprovido de saber algum e, portanto, de agora em diante quer saber sobre aquilo que passou a fazer falta. Isso que se quer saber, o aprendiz o supõe no mestre, a tal ponto, de pretender usufruir um pouco dele, ofertando, em troca, seu amor, bem como demandando àquele o restante para, assim, ambos fazerem UM, a quem nada falte. Aquilo que o aprendiz deseja é impossivel pois, por um lado, se porventura o fosse, então, acabaria a própria razão que move sua existência, ou seja, o desejo. E, por outro, o mestre não pode, de fato, entregar aquilo que não possui no real. Entretanto, o mestre de plantão - sabedor do impasse que aprisiona a ambos - doa simbolicamente aquilo que, embora não tenha, conhece onde tomar emprestado. É verdade que dessa maneira não entrega o pedido, mas, enquanto cumpre com seu dever, abre para o aprendiz as possibilidades de uma existência educada.

Por exemplo, aquele mestre, um pouco matemático, na medida em que ensina, inocula o germe da razão que impera no mundo dos números, mostra um certo saber, bem como leva o aprendiz a demandar seu amor, na exata proporção daquilo que não pode ser 
ensinado. Assim sendo, seria uma tolice da sua parte pretender entregar o pedido, pois, em primeiro lugar, a satisfação do aprendiz se esfuma com a mesma rapidez que uma miragem no deserto; em segundo lugar, uma vez desfeito o feitiço e dependendo do tamanho do ódio desencadeado, o iludido passa tanto a recusar a educação quanto a lhe infernizar a vida; e, em último lugar, estaria renunciando a seu dever de honrar a dívida que tem com o mundo dos números. Nesse sentido, resta ao mestre ocupar sem vergonha, mas com sabedoria, esse lugar impossível. Fazendo semblante que sabe e que algum dia seu saber será do aprendiz, "dá tempo ao tempo", como gosta de repetir Maud Mannoni. O aprendiz apre(e)nde e, antes que seja capaz de perceber, estará a tal ponto atoladado em dívidas para com os números, que não só esquece de cobrar do mestre quanto passa a lembrar seu ensino em cada conta bem feita.

Em suma, o aprendiz entra na jogada apenas por amor, passa a querer saber e, logo mais, sem por isso renunciar totalmente à lembrança de seu primeiro encanto, ocupa seu tempo cotidiano tentando conhecer para si e para outros toda a razão que, alguma vez, o invadiu em estado germinal.

\section{O FRACASSO ESCOLAR E A SIMPLICIDADE DE UMA VIDA EDUCADA}

Chegados a este ponto, podemos concluir as obviedades seguintes:

- a possibilidade factual da educação se confunde com a viabilidade própria da vida cotidiana ou, em outras palavras, subjetividade e educação se pressupõem mutuamente.

- a legalidade do ato educativo resulta do contraponto entre um dever- ser, mais ou menos cumprido, e um amor, em última instância, não correspondido.

Claro está, algum leitor pode considerar que essas conclusões não são tão óbvias assim e que, mais ainda, deveriam se realizar estudos "científicos" no sentido de avaliar a pertinência das mesmas. Porém, permitimo-nos discordar, pois, embora a vida tenha seus mistérios, às vezes tem coisas óbvias demais.

Pensar que o ato educativo é factivel na proporção de uma adequação naturalmente bem sucedida entre, por um lado, capacidades maturacionais e, por outro, estratégias científicas de ensino é um traço característico do pensar moderno (cf. de Lajonquière, 1992, 1996). Mais ainda, constitui uma prova indubitável da pressa na qual incorrem certos espíritos (psico)pedagógicos.

Com efeito, se a educação fosse possível apenas na presença dessa condição, então se deveria concluir que há tantos métodos adequados quanto atos educativos bem sucedidos. Porém, se há de faso tantos métodos supostamente adequados, então, cai por terra a tese de uma adequaçâo natural, e, portanto, o raciocínio hegemônico revela-se contraditório. Claro está, no intuito de esconder essa inconsistência, poder-seia acreditar que algum dia nos encontraremos tête-à-tête com o suposto e verdadeiro método natural de sorte que, assim, passaríamos a ficar livres dos simulacros metodológicos - pães nossos de cada dia. Mas, se porventura alguém raciocinasse nesse sentido, então estaria professando o mais puro platonismo que, à vista de alguns, seria incompatível com o espírito de certas posturas pedagógicas hoje em voga. Como vemos, se corremos o bicho nos pega e se nos detemos estamos perdidos.

Por outra parte, a pretensão de justificar o fracasso educativo pela falta 
de adequação natural revela-se também ilusória quando da aproximação tanto histórica quanto comparativa à problemática.

De fato, os livros de história da educação nos informam, dentre outras curiosidades, que não foram poucos os séculos nos quais os aprendizes, de qualquer teor e gênero, não só copiavam e decoravam quanto "eram tão capacitados" que aprendiam coisas que, hoje, são consideradas não acordes à "linha natural de desenvolvimento infantil". Alguém poderia contra-argumentar que desconhecemos se esses alunos de outrora aprendiam ou, mais ainda, se "construiam seu conhecimento", ou apenas decoravam o ensinado. Essas dúvidas não nos surpreendem, bem como parecem-nos totalmente improcedentes uma vez que, se nossos antepassados não tivessem aprendido, então, todos nós seríamos extraterrestres, pois se teria interropido, há algum tempo, a transmissão histórica. Nosso contra-argüidor bem poderia, agora, retrucar que, talvez, se tratasse apenas de uma minoria que aprendia. No entanto, esse argumento é estatística e historicamente inviável. Por um lado, se sempre se tratou de uma minoria, então, a taxa de instrução deveria ter sido historicamente regressiva e não crescente, como bem mostram os censos em muitos países, inclusive os latinoamericanos, na passagem do último século. Por outro, não consta que o não-aprender tenha merecido registros específicos. A esse respeito, é um desatino afirmar que nossos antepassados eram insensiveis ao fracasso escolar, não the dedicando dissertações e estatísticas. Justamente, se não mereceu ser registrado é, pelo contrário, porque não era de fato preocupante. Nesse sentido, cabe lembrar que no famoso Dictionnaire de Pédagogie de Ferdinand Buisson, publicado em 1887, não cons- ta o verbete fracasso escolar. Assim sendo, é plausível que o sistema escolar tenha começado a fracassar após essa data que, por sinal, coincide com o início do processo de psicologização do cotidiano escolar (cf.Hébrard;s/d).

A aproximação comparativa à problemática do fracasso escolar nos esclarece, também, sobre a insconsistência que se aninha no seio do discurso (psico)pedagógico hegemônico. Recentemente, tomamos conhecimento, de forma casual, de que a República da Mongólia possui uma taxa de analfabetismo da ordem de $3 \%$. Esse fato não seria nada instigador se não fosse que a mesma matéria jornalística nos informa que $30 \%$ da população é nômade. Mais ainda, para complexizar o quadro da situação, ficamos sabendo, consultando um Atlas Geográfico, que no país há duas línguas oficiais (mongol khalkha e cazaque).

Como será que o povo mongolóide garante educação básica para a imensa maioria quando não poucos têm esse costume "primitivo" de se deslocar o tempo todo, assim como para complicar mais ainda, o de ser bilíngues? Como será que uma nação consegue isso, que para nosso país parece ser impossível, mesmo não ostentando uma economia capitalista capaz de pôr maciçamente em circulação parabólicas, aparelhos de TV, microcomputadores, retroprojetores e demais quinquilharias pedagógicas? Infelizmente, carecemos de maiores informações sobre esse, ao que parece, simpático, país centro-asiático. Entretanto, estamos dispostos a correr o risco de afirmar que, por um lado, a "metodologia de ensino" utilizada deve ser a clássica, isto é, "quem sabe ensina e quem não sabe aprende", e, por outro, a política educacional deve consistir em garantir a factibilidade dos encontros entre aqueles que já sabem (e são respeitados pelo principe) e 
aqueles que ainda não sabem, bem como em conferir - apesar, é claro, da imperfeição irredutível da vida - que por exemplo, embora o tempo passe, $2+2$ continua sendo 4 para a imensa maioria da população.

Se porventura estamos com a razão, o leitor não deveria se surpreender. Como sabemos, faz tanto tempo que os mongolóides são vizinhos dos chineses que estão plenamente convencidos que, nesta altura da história, não tem mais sentido querer inventar a pólvora. Obviamente, a Mongólia deve garantir a instrução básica da mesma forma clássica que o fazem muitos outros países que ostentam, também, taxas semelhantes ou até melhores de alfabetização.

Nesse contexto, nosso incansável contra-argüidor pode, agora, replicar que nesses outros países os habitantes foram agraciados pela natureza com capacidades maturacionais de qualidade superior às nossas. Esse argumento, embora passivel de ser esgrimido em se considerando o biologicismo grosseiro que muitos professam, é improcedente por duas razôes. Por um lado, se fosse por causa de um azar mutacional, ocorrido por volta dos anos 60 , que as supostas capacidades maturacionais da clientela escolar brasileira sofreram um dano capaz de provocar a detenção do processo crescente de instrução registrado até esse momento, então, dever-se-ia simplesmente desistir de toda empresa educativa. Com efeito, para quem raciocina nessa direção, seria congruente, e até mais econômico, esperar por uma outra mutação capaz, nesta oportunidade, de tirar a nação do marasmo educacional. Por outrỏ lado, uma mutação tão azarada deveria necessariamente ser obra de um gênio maligno. Mas essa hipótese é indefensável, pois, como todos sabemos, o fato de Deus ser brasileiro torna improvável o agir de seres semelhantes em todo o território nacional.
Ora pois, se hoje em dia a taxa de instrução, ou está estacionada, ou apenas cresce artificialmente (pois há diplomas que não atestam o que se supõe) ou, por último, não aumenta o que deveria, em se considerando os recursos totais investidos, não se deve ao fato de não ter ainda se descoberto a fórmula da adequaçâo natural. Deixando de lado a pergunta por que Pedrinbo não aprende? - apenas pertinente quando da articulação de um campo clínico de interrogação- afirmamos que a maioria da população de qualquer país não aprende porque, simplesmente, a nação em questão não consegue equacionar, segundo uma lógica expansiva, a possibilidade própria da educação.

Infelizmente, a história recente de nosso país nos mostra como é possivel sucatear a legalidade inerente à simplicidade da transmissão educativa.

\section{A EDUCAÇÃO DA CRIANÇA E O HOMEM MODERNO}

A educação marca os sujeitos enquanto semelhantes. Porém, sermos semelhantes não significa que sejamos iguais ou que cada um seja a répliça de um outro. Com efeito, parte do que se transmite em todo ato educativo se repete, mas uma outra parte se perde de maneira que, ao todo, a marca na sua repetição acaba diferindo. Assim, a própria transmissão que, por um lado, da mesma forma que assemelha também carrega o germe da diferença entre mestre e aprendiz, por outro, realimenta o processo reconstrutivo dos conhecimentos, ao mesmo tempo que abre a possibilidade de que aconteça uma maior ou menor revolução estrutural, como bem mostra a história das epistemes.

Toda transmissão tem lugar no 
interior da linguagem e através de uma lingua oral ou de sinais qualquer. Como sabemos, não consta que alguma vez não tenha sido assim. Mas também, trata-se de uma conclusão à qual o leitor pode chegar. Por exemplo, se tenta ensinar a outro que $2+2=4$ fará uso de uma língua determinada ou, por diversos motivos que nunca faltam, tentará inventar uma usando retalhos de outras mais ou menos conhecidas. No entanto, se porventura o leitor não é aquele que ensina mas seu interlocutor, chegará também a idêntica conclusão visto que tomará cada gesto ou palavra do mestre como elementos de uma língua singular, pois para quem habita a linguagem tudo é signo de alguma outra coisa mesmo que não saiba do que se trata. Assim, não há educação que não se sirva de uma língua e, portanto, que não pressuponha a linguagem. Mais ainda, como a estrutura da linguagem é de natureza remissiva, ou seja, trata-se de uma rede de diferenças, o transmitido, via uma língua, está condenado tanto a se repetir quanto a diferir. Em suma, o ato educativo tanto filia sujeitos e conhecimentos quanto abre a possibilidade de que se opere uma ruptura respeito des si mesmo.

A impossibilidade de resolver numa sintese totalizadora os vectores repetição e diferença faz, precisamente, da educação uma empresa impossível, no dizer de Freud. Com efeito, essa contradição insuperável inviabiliza o fato do aprediz vir a ser uma réplica do mestre e não, como às vezes se pensa, a mesmíssima transmissão educativa. Nesse mesmo sentido, Freud alertava analistas e governantes da impossibilidade factual de se fazer dos analisantes e dos cidadãos réplicas de si próprios. Assim, à medida que essa tensão contraditória é equacionada a educação vira um fato ou, em outras palavras, o equacionamento da impossibilidade de fabricar replicantes torna a priori possível que a educação venha de fato a acontecer.

Neste contexto, cabe afirmar que se a educação, em se considerando o tamanho do fracasso escolar atual, parece ser de fato impossível ou, chegado o caso, um processo que em si mesmo requer uma sofisticação tecnológica inatingivel, semelhante situação resulta de uma espécie de curto-circuito na simples legalidade que anima todo ato educativo. Mais ainda, essa falha que desgarra a transmissão de conhecimentos e saberes é tanto o álibi esgrimido pelo discurso (psico)pedagógico hegemônico, na tentativa de legitimar sua pertinência, quanto o efeito paradoxal das providências tomadas em seu próprio nome, no intuito suposto de garantí-la "cientificamente".

Esse curto-circuito na transmissão ocorre pelo embaraço do contraponto entre o dever-ser e a demanda de amor. A fórmula tradicional acabou no decorrer do tempo se convertendo nesta outra: ensinar e aprender por amor. Justamente, esse mandato é a priori insustentável até as últimas consequências, pois sendo a expressão de uma lógica narcísica está, como sabemos, condenado a sua própria fagocitose.

Semelhante alteração na razão educativa exprime uma mudança geral na relação adulto-criança. À diferença de outrora, os adultos de hoje, quando se endereçam a uma criança, não o fazem em cumprimento de um deverser retroativo, mas no intuito de procurar satisfazer as demandas de "bis majesty the baby", lembrando a expressão freudiana. É precisamente na proporção do narcisismo embutido no amor parental que todo adulto, seja ou não de fato pai, visa poupar à criança das leis da natureza e da sociedade (cf.Freud;1973b:2027). Dessa forma, cada vez que um adulto se endereça a 
uma criança não é improvável que experimente a queda de vir a poupá-la de todo tipo de restrições. Infelizmente, se porventura assim o for, a legalidade educativa não pode menos do que acabar sendo embaralhada.

Como o ato educativo é possível na medida do equacionamento de uma dívida simbólica, ou seja, do reconhecimento de uma obrigação por parte do adulto em posição de mestre, então, constitui um paradoxo mortal pretender educar e, ao mesmo tempo, almejar que as leis percam sua validade perante as crianças. Em outras palavras, todo ato educativo alimentado pela ilusão de que a criança possa de direito vir a driblar a lei, está a priori condenado ao fracasso, uma vez que se auto-esvazia. Isso é inevitável, pois quando o adulto almeja poupar à criança das restrições inerentes, em última instância, à lei da vida humana, abre a possibilidade de uma exceção que mina os próprios fundamentos do ato educativo - o fato de o adulto estar engajado no mesmo, apenas em cumprimento de um dever-ser existencial. Não há do que nos surpreender: ou todos estamos obrigados por igual ou não há lei.

Como sabemos, a cota de narcisismo depositada na criança idealiza-a ao ponto tal que o adulto quando olha nos idealiza-a a tal ponto que, o adulto quando olha nos olhos dela, recupera a felicidade que acredita ter perdido ou da qual supõe estar sendo privado. Assim, do fundo desse olhar, retornalhe sua própria imagem refletida às avessas ou, em outras palavras, quando olha para uma criança e focaliza de fato aquela outra ideal, todo adulto consegue ver a si mesmo completo.

A eficácia desse feitiço dura o tempo de um instante. Portanto, o adulto, para manter viva essa ilusão, recorre a uma outra - aquela de ser possível aniquilar o tempo. Ou seja, cada vez que se depara com uma criança vê nela esse ao menos um adulto do futuro a quem nada falta. Isso que sempre falta ao/no presente é, precisamente, a distância que o separa de um ideal existencial. $\mathrm{O}$ adulto, em vez de experimentá-lo como uma impossibilidade factual e, por conseguinte, como uma dívida sempre simbólica, vive essa diferença no registro da impotência. Assim, na exata proporção do que experimenta como falta imaginária, espera que a criança venha a ser esse ao menos um a quem nada falte no futuro. Isto é, a ilusão da completude futura repõe imaginariamente aquilo que falta no presente.

Dessa forma, o adulto de hoje padece de uma certa propensão a degradar o estatuto simbólico da educação, pois, cada vez que se endereça a uma criança alimentando semelhante ilusão, acaba fazendo o possível para poupá-la das limitações inerentes à mesma. Mais ainda, é por essa razão que o adulto não pode não experimentar uma espécie de borror ao ato educativo, parafraseando Lacan, visto que as restrições nele embutidas ecoam subjetivamente como uma ferida narcísica.

O grau de pertinência suposta ao discurso (psico)pedagógico hegemônico é precisamente proporcional ao tamanho desse horror. Com efeito, a ilusão central em torno da qual esse discurso se articula é aquela de ser possível programar a fabricação de um ser ideal. Na medida dessa crença animada por semelhante voto narcísico, a educação, bem como o cotidiano escolar, se tensionam conforme um cálculo prospectivo. Tudo o que se faz realiza-se em nome de um futuro, enquanto avesso especular do que ao parco presente imaginariamente falta. Em outras palavras, o adulto não educa em razão de um dever-ser sempre a cumprir que emana do passado, mas em nome da quase certeza futurista embutida em toda teorização metódicopsicológica desenvolvimentista (cf. de Lajonquière, 1996). 
Como vimos, quando o adulto educa no cumprimento de um ideal não-narcísico, o ato em si mesmo equaciona uma dívida simbólica e, portanto, justifica-se apenas em nome da arbitrariedade própria do desejo. Assim sendo, o fato de o adulto invocar as previsões, bem como as prescrições inerentes às teorizações metodológico-desenvolvimentistas, acaba esvaziando o ato educativo. A imagem desse ao menos um adulto do futuro, que essas conceitualizações recortam no horizonte, formata a fenda mesma do desejo.

Nesse sentido, se o ato educativo articula-se de sorte que recusa o desejo que lhe outorga precisamente sustentação, então, a transmissão de saberes e conhecimentos se desgarra. O desgarramento dissipativo da transmisão educativa priva o aprendiz de plantão da possibilidade de usufruir da cota de existência humana que a mesma pressupõe e, portanto, deixa margem para que a criança em desenvolvimento revele, no futuro, ter sido na realidade uma tartaruga ninja adormecida.

O investimento narcísico da criança é um efeito necessário do espírito da modernidade articulado em torno da ilusão individual. O homem moderno pensa-se a si mesmo como um individuo a quem por direito nada pode faltar, uma vez que na sua origem está, precisamente, em causa a recusa de toda dívida para com uma tradição filiatória. Assim, degradando-se a referência existencial de natureza simbólica, o agora indivíduo passa a estar impelido a se segurar na vida graças à imagem de uma criança ideal. Por outro lado, essa imagem enquanto reverso especular de si próprio possibilita ao adulto moderno sentir, pensar e agir como um in/dividuo. Para manter incólume a crença na sua não-divisão subjetiva, o homem de hoje está obrigado a recusar a diferença que medeia entre um in/dividuo e outro, pois sempre lhe aparece como uma ferida mortal no miolo do ser. Entretanto, essa diferença é a distância irredutível que todo sujeito mantém a respeito do ideal e que, por conseguinte, alimenta o mesmíssimo desejo. A imagem ideal desse ao menos um adulto do futuro resulta ser o somatório das infinitas feridas narcísicas que tọdo homem moderno sofre em razão de o semelhante não ser sua própria réplica.

A ilusão individual é inerente à modernidade. No entanto, disso não decorre necessariamente que o homem moderno deva sustentar sua existência, apenas, na recusa da diferença que há entre ser semelhantes e ser imaginariamente iguais. Semelhante confusão só pode ser resultaḋo de um malentendido no decorrer do tempo. Com efeito, o espírito moderno também sentenciou Liberté, Egalité e Fraternité. A igualdade pressuposta nessa tão clássica quanto moderna fórmula é, ao contrário, uma igualdade de natureza simbólica. Assim sendo, ela nos faz fraternos ou semelhantes perante a obrigação de cumprir as leis da polis. Cabe lembrar que é em nome dessa igualdade simbólica que, chegado o caso, uma lei permite seu próprio não-cumprimento. Por exemplo, o mandato de não-matarás é solidário da figura jurídica de matar 
em legítima defesa. Justamente, sem exceções desse tipo uma ordem jurídica articularia apenas igualdades imaginárias.

Nesse contexto, o fato de uma sociedade estar tomada por uma lógica narcísica onipresente parece-me não ser um desdobramento inelutável do espírito moderno. Pelo contrário, perece-me ser apenas o indicativo de que o indivíduo esqueceu o espírito das leis em nome do qual veio precisamente à luz. Claro está, esquecimento que, embora seja involuntário, permite a alguns, por exemplo, enriquecer ilegitimamente às custas da maioria.

Assim, talvez caiba afirmar que o tamanho do dito fracasso escolar que assola um país é diretamente proporcional à degradação de suas leis ou, se preferirmos, ao tamanho da renuncia à educação. Obviamente, não se trata de nada que não se possa mudar, conquanto não esqueçamos que "a escola e a senzala são pólos que se repelem”, como alertou Joaquim Nabuco (1988,p.137).

\section{REFERÊNCIAS BIBLIOGRÁFICAS}

CALLIGARIS, C. (1993).Sociedade e individuo. In: FLEIG, M. Psicanálise e sintoma social. São Leopoldo: Editora Unisinos, p. 183-196.

(1995). Três Conselhos para a Educação das Crianças. In:

CALLIGARIS, C. et alii Educa-se um criança ? Porto Alegre: Artes e Ofícios, p. 25-30.

CASTORIADIS, C. (1992). Psicoanálisis y política. Diarios Clínicos, n. 4, p. 19-31 [1987].

CORAZZA, S. (1995). Poder-Saber e ética na escola. Ijuí: Editora Unijuí.

COROMINAS, J. (1954).Diccionario crítico etimológico de la lengua castellana. Madrid: Editorial Gredos.

de LAJONQUIÈRE, L. (1992). O legado pedagógico de Jean Itard. A pedagogia: ciência ou arte ? Educação e Filosofia, v. 6, n. 12, p. 37-51.

(1993).De Piaget a Freud: para repensar as apren-

dizagens. Petrópolis: Vozes.

(1994). pistemologia e psicanálise: o estatuto do

sujeito. Percurso. Revista de Psicanálise, v. VII, n.13, p.57-63.

(1995). Piaget e Freud: uma aproximação possível?

Anais da I Jornada de Psicologia da Educação, ano 1994, Universidade Federal de Pelotas, p. 7-16.

(1996). A criança, "sua" (in)disciplina e a psi-

canálise. In: AQUINO, J. (org.) Indisciplina na Escola, São Paulo:

Summus, p. 25-37.

(1997). A inteligência piagetiana. In: BANKS-LEITE,

L. (org.) Percursos piagetianos. São Paulo: Cortez (no prelo).

de LA TAILLE (1996). A indisciplina e o sentimento de vergonha. In:

AQUINO, J. Indisciplina na escola. op. cit., p. 9-23.

FREIRE-COSTA, J. (1991). Resposta a Octávio de Souza. In: TARLEI de

ARAGÃO, L. et alii Clínica do social. São Paulo: Escuta, p. 93-103.

(1991). Narcisismo em tempos sombrios. In:

RODRIGUES-FERNANDES, H. (org.) Tempo de desejo, 2da ed., São Paulo:

Brasiliense, p. 108-136. 
FREUD, S. (1973a). Sobre la psicologia del colegial. In: Obras Completas, v.2., Madrid: Biblioteca Nueva, p. 1892-1894 [1914].

(1973b). Introducción al narcisismo. In: Obras Completas, v.2, op. cit., p. 2017-2033. [1914]

(1973c). Prefacio para un libro de August Aichhorn. In: Obras Completas, v.3, Madrid: Biblioteca Nueva, p. 3216-3217. [1925]

(1973d). Analisis terminable e interminable. In: Obras

Completas, v. 3, op.cit., p. 3340-3364. [1937]

FIRMINO, N. (s/d). Dicconário latino-português. São Paulo: Melhoramentos.

GARCIA de DIEGO,V. (1982). Diccionario ilustrado latino-español, españollatino. Barcelona: Bibliograf.

HÉBRARD, J. (s/d). Instruction ou education. Ornicar? Bulletin Périodique du Champ Freudien, n. 26-27, p. 122-132.

JERUSALINSKY, A. (1993). O fantasma da lógica no social ou as razões científicas da corrupção. In: FLEIG, M. Psicanálise e sintoma social, op.cit., p. 13-25.

(1995). Apesar de você, amanhã há de ser outro dia.

In: CALLIGARIS, C. et alii Educa-se uma criança? op. cit., p. 13-23.

LACAN, J. (1985). O Seminário. Livro 11. Rio de Janeiro: Zahar Editor. [1964] [1959-1960]

(1996). O Seminário. Livro 7. Rio de Janeiro: Zahar Editor.

LICHTENSTEIN-CORSO, D. (1993). Parentalidade envergonhada. In: FLEIG,

M. (org.) Psicanálise e sintoma social. op.cit., p.169-182.

MACHADO, J.P, (1956). Dicionário etimológico da lingua portuguesa. Lisboa: Confluência

MANNONI, M. (1983). La educación imposible, México: Siglo XXI Editores. [1973]

NABUCO, J. (1988). O Abolicionismo. Petrópolis: Vozes. [1883]

PEREIRA, M.R. (1995). A transferência na relação ensinante. In: CALLIGARIS, C. et alii Educa-se uma criança? op.cit., p.207-216.

PONTES-SPÓSITO, M. (1994). Violência coletiva, jovens e educação: dimensões do conflito social na cidade. Cadernos ANPED, n.7, p.121-145.

SOUZA, O. (1991). Reflexão sobre a extensão dos conceitos e da prática. In: TARLEI de ARAGÃO, L. et alii Clínica do social. op.cit., p. 75-92.

SOUZA-PATTO, M.H. (1984). Psicologia e ideologia. São Paulo: Queiroz Editor.

VOLNOVICH, J.C. (1994). El análisis de la institución educativa. Diarios

Clinicos, n. 7, p. 121-126.

\section{NOTAS}

1 A criança, "sua" (in)disciplina e a psicanálise.

2 Desenvolvemos essa noção em $A$ inteligência piagetiana.

3 As noções saber e conbecimento são utilizadas amplamente na literatura. Entretanto, permitimo-nos utilizá-las, reiteradamente, segundo uma outra lógica muito precisa tanto nesta oportunidade quanto em outras. A esse respeito pode consultar-se De Piaget a Freud: para repensar as aprendizagens, bem como Piaget e Freud: uma aproximação possível?

4 A diferença entre saber sobre e saber de foi apresentada em $A$ criança, "sua" (in)disciplina e a psicanálise.

5 Dialética isomórfica àquela da oferta materna de uma imagem ideal no contexto da conceitualização da experiência especular; cf. De Piaget a Freud, p. 163-174. 